\title{
El matte painting en los diferentes regímenes de escritura cinematográfica
}

\section{Matte painting across the different film models}

Darío Lanza Vidal. Universidad Rey Juan Carlos (dario@dariolanza.com)

Recibido el: 30/09/15 - Aceptado el: 01/04/16

\section{Resumen:}

El matte painting es una técnica de efectos especiales utilizada para la creación de escenarios simulados mediante la combinación de un metraje rodado y un fragmento pintado. Dado que esta técnica ha constituido un recurso frecuente desde los orígenes del cine en propuestas narrativas muy diversas, cabría preguntarse si ha experimentado una distinta interpretación por parte de los diferentes regímenes de escritura cinematográfica o si, por el contrario, ha sido aplicado de una forma más o menos homogénea en todos ellos. ¿Cómo han interpretado los regímenes clásico, barroco, moderno, postmoderno y el actual neobarroco digital este efecto especial? Los resultados muestran claramente cómo cada régimen ha moldeado y adaptado sus pinturas de acuerdo a su particular concepción del espacio y el escenario.

Palabras clave:

Matte painting; régimen escritura; clásico; barroco; postmoderno; neobarroco.

\section{Abstract:}

Matte painting is a special effects technique used for the creation of simulated sets by the means of combination of a filmed plate and a piece of painting. Given that since the birth of cinema it has been a frequent resource used on very different narrative models, we could ask whether it has experienced different interpretations from the different film models or if, otherwise, it has been applied in a more or less uniform fashion by then all. How the classical, baroque, modern, post-modern and the current digital neo-baroque film models have interpreted this special effect? The results of this work clearly show how each film model has shaped their paintings according to its particular conception of space and scene.

Keywords:

Matte painting; film model; classical; baroque; post.modern; neo-baroque. 


\section{Introducción}

En el film Napoleon (Abel Gance, 1927), en la secuencia en la que el himno "La Marsellesa” es presentado por primera vez ante los revolucionarios franceses reunidos en asamblea, vemos a su compositor subido a un púlpito cantando apasionadamente en una vista del interior del convento de los Cordeliers en París (figura 01). Dicho escenario no era una localización real, sino la combinación de un decorado y un pequeño fragmento de cartón sostenido delante de la cámara en el que se había pintado toda la arquitectura de la estancia, incluyendo las columnas, los arcos, los ventanales e incluso los haces de luz que se abren camino a través de las vidrieras. Este es uno de los muchísimos planos en los que el espectador, sin ser consciente de ello, está en realidad contemplando una pintura, un ejemplo de la técnica que conocemos como matte painting, creaciones que fusionan las artes cinematográfica y pictórica y a las que el cine ha recurrido con considerable frecuencia, y que, sin embargo, no han gozado de suficiente atención salvo en un reducido conjunto de manuales, y siempre desde enfoques meramente históricos como Vaz and Barron (2002) y Rickitt (2006) o exclusivamente técnicos como Sawicki (2007) o Mattingly (2011). Tratando de plantear un análisis de este fenómeno desde su aportación a la escritura fílmica y siendo como decimos un recurso habitual a lo largo de la historia del cine por propuestas narrativas muy diversas, nos preguntamos: ¿se podrían encontrar características diferenciadoras entre los matte paintings de los regímenes clásico, barroco, moderno, postmoderno y el actual neobarroco digital? El presente trabajo tratará de responder a esta pregunta.

Figura 01. Napoleon. Matte painting de Walter Percy Day.
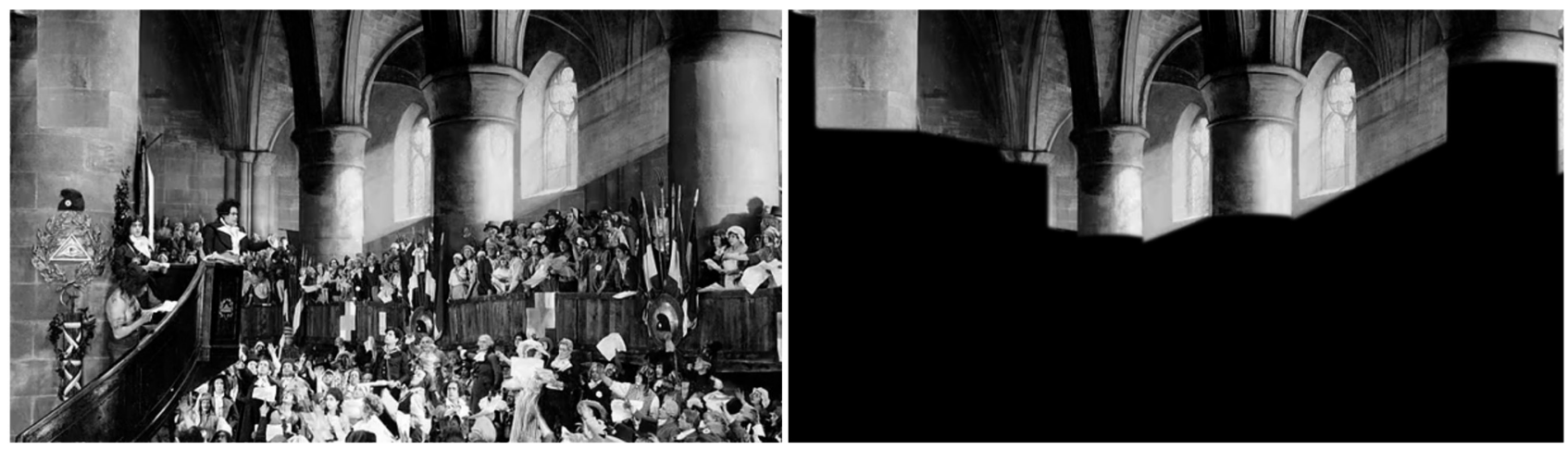

En su acepción más extendida, el término matte painting describe, en cinematografía, una técnica de efectos especiales utilizada en la creación de escenarios simulados que emplea la representación pictórica del escenario en un soporte de reducidas dimensiones y su posterior inserción y composición con el metraje rodado mediante procedimientos ópticos, fotográficos o digitales. Una definición más precisa sería la que proponemos aquí: "matte painting, imagen bidimensio- 
nal, producida a mano o mediante cualquier medio mecánico, fotográfico o digital, habitualmente con vocación de escenario, diseñada para reemplazar de forma ilusionista todo o una parte de un cuadro cinematográfico".

Dado que el matte painting sutura un espacio real filmado con un espacio virtual pintado, actúa como un verdadero mecanismo ensamblador de espacios, un montaje de superficie que opera dentro del cuadro -a diferencia del auténtico montaje cuya yuxtaposición se articula en la cadena temporal- y por medio del cual el significante espacial es construido por sutura de fragmentos a partir de, al menos, un elemento de naturaleza pictórica.

Habida cuenta de la recomendable cautela con que conviene aplicar toda categorización estilística en cualquier arte para minimizar el riesgo de resultar reduccionista, en el presente trabajo emplearemos la tradicional taxonomía de modelos de escritura fílmica que reconoce los regímenes clásico, barroco, moderno, postmoderno y el reciente neobarroco digital, y describiremos cómo las características particulares de cada régimen han moldeado los matte paintings que se desarrollan en su seno. Hemos de resaltar la prudencia con la que entendemos las categorías mencionadas, que emplearemos como herramientas para el análisis histórico, pero que en ningún caso constituyen categorías estancas ni apuntan a una filiación evolutiva. Prescindiremos además del análisis de los matte paintings en el modelo de representación primitivo, pues siendo esta una técnica nacida en 1907, su relativa escasez durante el período primitivo hace difícil extraer un conjunto cohesivo de características comunes.

Dicho esto, nos preguntamos: ¿sería posible reconocer unas características particulares y diferenciadoras entre los matte paintings de los regímenes clásico, barroco, moderno, postmoderno y neobarroco digital? Y si es así ¿cuáles serían dichas características?

\section{Hipótesis}

En última instancia el matte painting se postula como un recurso de la producción cinematográfica orientado a reducir los costes de la creación escenográfica allí donde la construcción material de escenarios o el desplazamiento a localizaciones reales resulte imposible o poco recomendable. En estas condiciones, el matte painting ofrece una solución económica de gran flexibildad capaz de proporcionar al realizador una ilimitada libertad creativa y al mismo tiempo reducir los costes de la producción. Sin embargo en este estudio, al margen de la motivación económica, queremos contemplar al matte painting como parte de la puesta en escena y del diseño escenográfico del film, y por tanto, al igual que el resto de mecanismos narrativos, como posible portador de una carga significante. De ser así, debería por un lado sernos posible diferenciar los matte paintings desarrollados bajo estilos narrativos distintos y por otro permitirnos reconocer las particulares características discursivas de un determinado modelo de escritura en las pinturas que este haya desarrollado. Demostraremos cómo este recurso técnico de ahorro de costes es capaz de impregnarse de las características de la escritura en la que se articula y cómo resulta efectivamente posible apuntar a un conjunto de rasgos comunes a las pinturas desarrolladas bajo cada modelo narrativo. 


\section{Metodología}

Para el presente estudio se ha procedido al análisis de ejemplos de matte painting presentes en una colección de textos característicos de cada uno de los diferentes regímenes de escritura fílmica. Para la selección de films se han escogido textos suficientemente representativos de su respectivo régimen de escritura de forma que pudieran reconocerse con nitidez las particularidades de su modelo narrativo y que al mismo tiempo hayan recurrido al matte painting para la creación de sus espacios escenográficos. En cada matte painting han sido analizadas las características formales y estilísticas de su interpretación del paisaje y el espacio, tanto en el plano pictórico -distribución de las masas, composición, paleta de colorcomo respecto a su nivel de significación en el relato. Ello nos ha permitido trazar un mapa de propuestas pictóricas y regímenes cinematográficos y reconocer los vínculos entre aquellas y estos.

\section{El matte painting en el régimen de escritura clásico}

Dado que con seguridad no es necesaria una caracterización pormenorizada del régimen de escritura clásico por tratarse de un tema sobradamente documentado, nos limitaremos aquí a resaltar aquellas de sus características que conciernen a su particular concepción del espacio y el escenario. Por cine clásico se entiende aquel régimen de escritura cinematográfica narrativa construido esencialmente en torno a la inmersión e identificación del espectador en la historia narrada, para lo que se supeditan todos los recursos constructivos en pos de una óptima representación del relato. Esta sería posiblemente la cualidad principal y más característica del régimen clásico: su decidida subordinación al sentido. Todos los mecanismos discursivos están aquí encaminados a garantizar la máxima claridad e inteligibilidad de lo narrado, apoyando como una sola voz al relato y evitando al máximo cualquier ambigüedad aún a costa de abundar en informaciones redundantes. Esta característica es a lo que Revault d'Allonnes (2008: 29) se refiere cuando califica este régimen de sobresignificante.

El relato clásico inhibe en lo posible toda multiplicidad de interpretaciones, obligando a todos los recursos, desde el propio planteamiento de la trama hasta el montaje, pasando por la puesta en escena o la iluminación -y la escenografía no será menos- a estar coordinados en apoyo del sentido obvio de la narración, conduciendo a una interpretación del relato única y sin contradicciones.

Esta construcción unidireccional se levanta sobre los célebres imperativos de verosimilitud, ocultación de los mecanismos discursivos y legibilidad máxima del discurso. El clasicismo construye una representación suficientemente maquillada para que al tiempo que remitir a una hipotética realidad, permita acoger la fuerte intervención operada por la enunciación en apoyo de la narración. No se trata de perseguir el realismo como objetivo, sino de emplear las necesarias dosis de verosimilitud para aportar credibilidad y tapar la constante manipulación de los recursos. De esta manera la diégesis se postula como una realidad alternativa a la real. El cine clásico te dice: "esto es realidad". 
La extrema legibilidad que busca el texto clásico afecta por supuesto a todos los elementos de la narración, incluyendo obviamente recursos como la iluminación, el diseño escenográfico o la composición visual del encuadre. Así, vemos que el cine clásico impone a sus encuadres una estudiada ordenación, tanto del espacio que se describe como del movimiento de los personajes, de manera que en todo momento se conforme un cuadro fácil de interpretar. La composición del encuadre clásico, en lo que a distribución de las figuras en la pantalla, se basa en los preceptos heredados del medio escénico de centralidad, equilibrio y frontalidad, en busca de maximizar la legibilidad de la imagen. Además de la organización superficial resulta destacable ver cómo el encuadre clásico también aprovecha activamente la composición en profundidad y distribuye los elementos en diferentes planos aprovechando la tridimensionalidad del espacio, consiguiendo con todo ello un cuadro muy compensando, cuidadosamente elaborado y medido. De esta manera el encuadre clásico se convierte siempre en el encuadre ideal, el lugar del príncipe, que facilita al máximo tanto narración como recepción.

Dicha cuidada elaboración del espacio se transmite a los matte paintings de este régimen, que también exhiben esta cuidada composición y distribución de las masas. Así lo encontramos, por ejemplo, en la pulcra construcción del lujoso apartamento de Nana (Jean Renoir, 1925). Tanto la escalera como el piso inferior eran un decorado construido en estudio, sin embargo el resto del encuadre era un matte painting, obra de Walter Percy Day (figura 02).

En esta pintura se identifican todos los principios compositivos del encuadre clásico. El autor representa el espacio frontalmente, distribuyendo las masas de forma perfectamente simétrica. Cada elemento de la decoración, cada barandilla, cada columna, cada puerta, cada lámpara, cada artesonado e incluso cada pintura del techo se encuentran replicados al otro lado del encuadre, resultando una composición simétrica y exquisitamente equilibrada. De esta manera, una recargada y suntuosa decoración que de otra forma podría derivar en una vista compleja y confusa, se muestra claramente legible. La escalera funciona como un zigzagueante eje de simetría que, unida a la frontalidad de las líneas perspectivas, conducen de forma inevitable la mirada hacia un único punto, la habitación de Nana destacada en el centro del cuadro. El diseño del escenario en su conjunto y del matte painting en particular se orientan a priorizar la legibilidad de la imagen. Equilibrio y claridad compositiva para provocar una lectura sencilla del cuadro. En esta pintura es incluso visible la célebre "T" bordwelliana, el esquema compositivo que según Bordwell siguen mayoritariamente los planos clásicos, en los cuales se privilegia el tercio superior horizontal y el tercio central vertical de la pantalla, definiendo una región en forma de "T" donde se ubican los elementos más importantes del plano (Bordwell, 1997: 56). 
Figura 02. Encuadre ideal. Equilibro, simetría y frontalidad en Nana. Matte painting de Walter Percy Day.
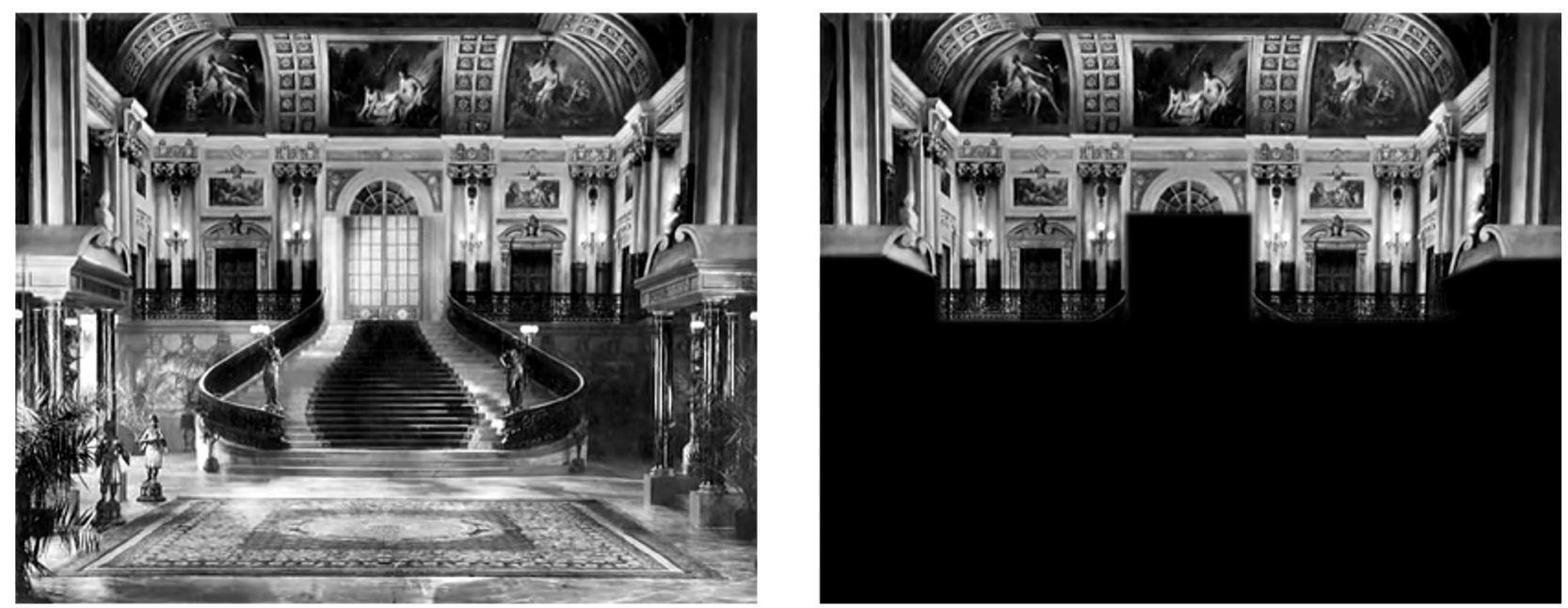

Otra manera de reforzar la legibilidad de la narración clásica es jerarquizar los elementos de la imagen en función de su relevancia en la cadena causal del relato, empleando iluminación selectiva, ubicación, color, textura y enfoque de cámara para visibilizar la importancia de cada elemento en la narración y dirigir con precisión la mirada del espectador por la pantalla. Para el autor clásico todo elemento debe estar jerarquizado basándose en su trascendencia narrativa, y lo principal en el encuadre clásico siempre es el personaje. Vestuario y escenario ocupan un papel secundario en dicha jerarquía, subordinados al personaje y a la cadena causal que subyace bajo todo el relato. "La escenografía va dirigida al espectador" (Bordwell, 1997: 60). Con estas palabras Bordwell subraya la que hemos destacado como la principal característica del régimen clásico: al igual que sucede con todos los demás recursos, el espacio y el escenario clásicos se ponen al servicio del sentido obvio, pasan de elementos meramente locativos a convertirse en significantes de pleno derecho, convergiendo todos en una misma dirección. El relato clásico persigue que todas las sensaciones suscitadas por todos los elementos de la narración operen en la misma dirección que el sentido de la obra.

También esta subordinación al sentido es fácilmente detectable en los matte paintings del régimen clásico. Y para comprobarlo, si hay un film que destaque por el número y calidad de sus matte paintings, nítidos ejemplos de matte painting clásico, este sería Lo que el viento se llevó (Victor Fleming, 1939), a su vez producto canónico del cine clásico de Hollywood. El film contiene cerca de un centenar de matte paintings (Vaz y Barron, 2002: 86), un número extraordinariamente elevado para la época, pintados por el matte painter Jack Cosgrove. Todos los elementos de esta narración se encuentran por supuesto poderosamente dramatizados en apoyo al relato, y en concreto todo el diseño artístico elaborado por William Cameron Menzies en lo referente a iluminación, color, fotografía, vestuario, escenografía y con ellos por supuesto también 
los matte paintings, se orienta unidireccionalmente a mostrar y subrayar el relato de los cambios de fortuna en la vida de Escarlata O'Hara.

Así por ejemplo, en la secuencia inicial, en el plano que muestra a Escarlata saliendo enfurecida de Tara en un arranque de celos tras conocer el compromiso de su pretendido Ashley Wilkes (figura 03), una porción muy considerable del cuadro -toda la mitad superior de la imagen, incluyendo la parte superior del caserón- son en realidad una pintura, que por supuesto se hace ver como un espacio físico y real. Verosimilitud formal para mantener invisible el acto narrativo y la profunda manipulación que hay detrás de lo que estamos viendo. También esta pintura es un claro ejemplo de la minuciosa composición del matte painting clásico. La imagen se encuadra entre dos potentes árboles simétricos que cierran la composición sobre sí misma y proporcionan una equilibrada marginación lateral que guía la mirada hacia el centro. El desplazamiento de Escarlata, del fondo hacia el frente, unifica el espacio, lo dota de tridimensionalidad y permite describirlo en toda su profundidad. La imagen se encuentra fuertemente jerarquizada, asignando la mayor importancia visual a la figura de Escarlata. Nada hay más luminoso, más vibrante ni más dinámico que su vestido blanco, de forma que la atención se focaliza en la reacción de la protagonista y no se permite que se pierda en el entorno. El resto de tonos en la pintura se encuentran matizados para no rivalizar con los del personaje, utilizando colores sensiblemente menos saturados y brillantes, de manera que el escenario no se impone al personaje sino al contrario. Jerarquización que se traslada a la pintura para guiar el foco de atención hacia la protagonista y su motivación psicológica.

Al tiempo que impecablemente compuestos y estratégicamente jerarquizados, los matte paintings de estas secuencias iniciales, como el resto de la escenografía, participan claramente del sentido aportado por la enunciación y, al igual que esta parte del relato, resultan resplandecientes, exuberantes. El matte painting se dramatiza en apoyo al sentido obvio y como tal estas primeras pinturas muestran un diseño impecable, limpio y elegante, acorde con la despreocupada y lujosa vida de la familia O'Hara. La paleta de tonos pastel, la frondosidad de la vegetación y la arquitectura del caserón en esta pintura remarcan con rotundidad la acomodada vida de la caprichosa Escarlata en esta parte del film. Unicidad de mensaje sin ambigüedades.

Por el contrario, más adelante, durante la Guerra Civil y la posguerra, la vida de Escarlata se endurece, se torna difícil y peligrosa, y esto también es subrayado en los matte paintings. Si nos fijamos en la secuencia de la huida de Escarlata, Melania y Prissy hacia Tara tras el incendio de Atlanta, el plano muestra un paisaje desolado y arrasado por la guerra. Todo el cuadro es aquí realmente una pintura de Cosgrove, salvo el estrecho camino por donde circula el carruaje de las protagonistas, la columna de humo en movimiento y un par de elementos reales en primer plano. La composición de la pintura de nuevo es exquisita y está cuidadosamente organizada. El camino de tierra que serpentea hacia el horizonte amplifica la profundidad del espacio, divide el cuadro en dos mitades y opera a modo de columna vertebral de toda la composición, permitiendo que los escombros y cadáveres de los soldados caídos se dispongan a ambos lados del camino formando dos 
masas simétricas. Los árboles, ahora arrasados y calcinados, continúan sirviendo para enmarcar la imagen, cerrar la composición y equilibrar las masas a izquierda y derecha.

Lo que la pintura nos está presentando, mucho más allá de una mostración objetiva de la destrucción de la batalla, es un escenario plenamente dramatizado, completamente impregnado de la misma desolación y miseria que sienten las protagonistas, operando en refuerzo de ese mismo sentimiento. El paisaje se comporta aquí como un elemento expresivo en sí mismo, retórico. El sentido de la secuencia es obvio, no hay espacio para dobles lecturas o interpretaciones alternativas, y obvio es también el sentido que aporta el paisaje en la pintura. Los vibrantes colores de las pinturas anteriores son aquí reemplazados por una gama prácticamente monocroma de grises y ocres, reforzando la forma en que el despreocupado mundo de Escarlata se ha desvanecido, ha sido destruido y convertido en desolación y miseria. matte painting elocuente que narra la misma historia. La pintura viene ya codificada con el mismo significado del relato, es por tanto sobresignificante, en términos de Revault d'Allonnes. La comparación entre esta pintura y la de Tara de la secuencia inicial nos sirve como mostración simbólica del giro de la trama.

Más adelante en el film, terminada la guerra y tras contraer matrimonio con Rhett Butler, la situación de Escarlata vuelve a cambiar. Ahora próspera y adinerada, la vida vuelve a sonreírle y las pinturas de Cosgrove nos hacen conscientes de esta nueva etapa de felicidad. Regresan los vivos colores a la paleta, reaparecen los verdes, los azules y los árboles vuelven a pintarse con espesura y frondosidad. La casa que construyen en Atlanta y que aparece en estas pinturas, ostentosa y recargada, de colores saturados, es utilizada como sinónimo visual de la actitud de Escarlata en este momento, nuevamente orgullosa, presuntuosa, caprichosa y superficial.

Figura 03. Matte painting dramatizado. Pintura subordinada al sentido en Lo que el viento se llevó. Matte paintings de
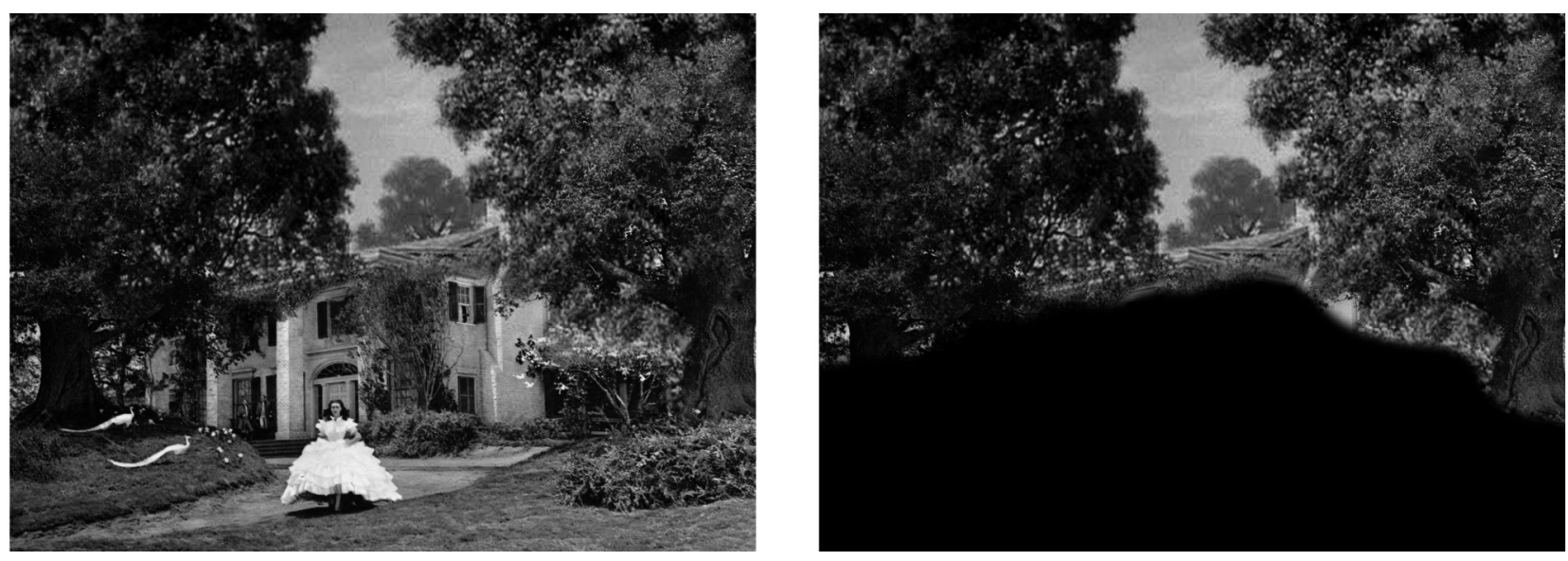

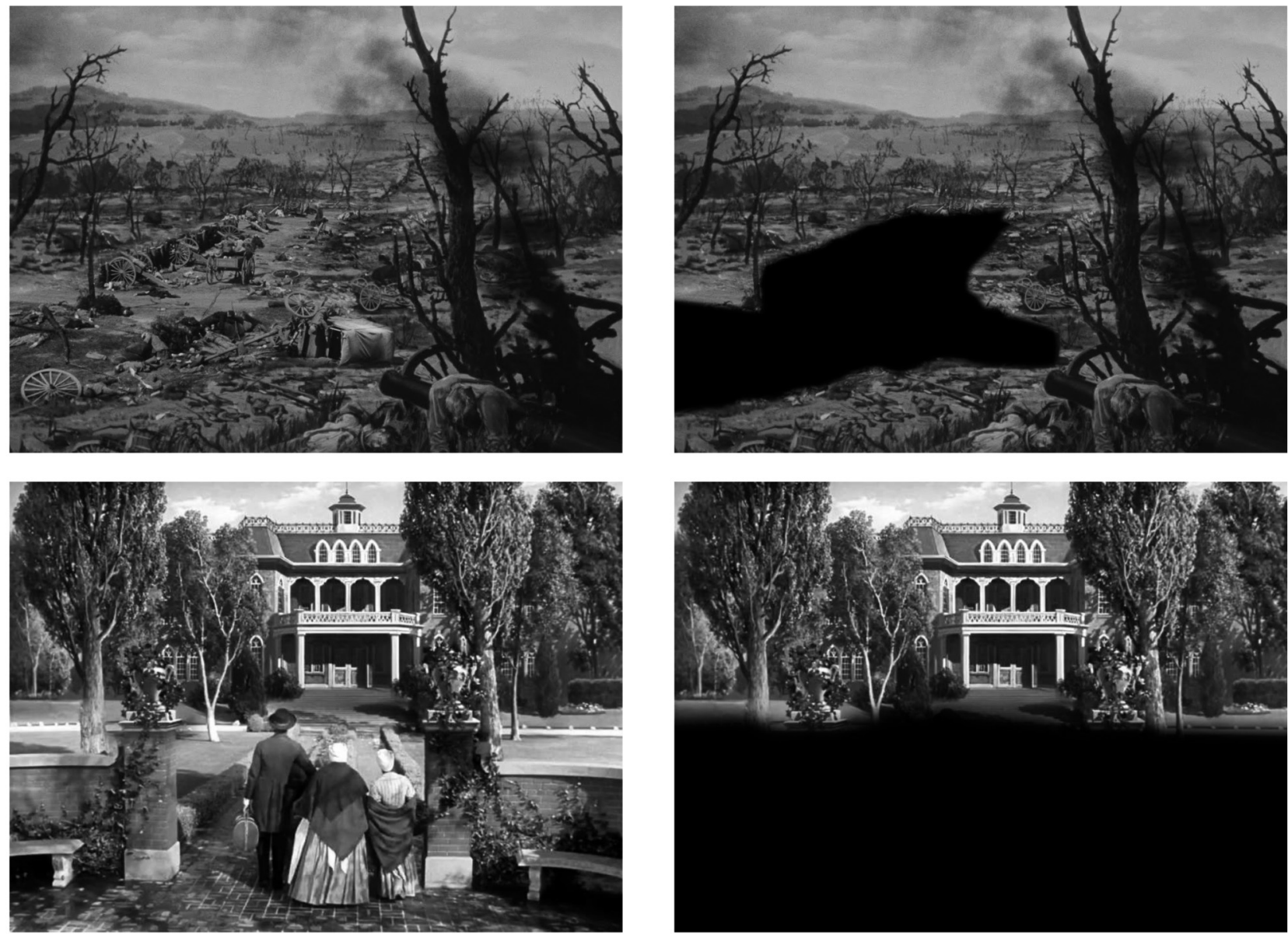

En estos matte paintings encontramos una correlación exacta entre el diseño de la pintura y el desarrollo de la trama, las principales características del relato clásico son transferidas puntualmente a sus matte paintings. Aquí, en el régimen clásico, el matte painting, mostrándose dramatizado y elocuente, se convierte en el retrato, pintado, explícito y visualmente aprehensible de la situación psicológica del personaje.

De hecho, el matte painting, con su extraordinaria flexibilidad expresiva, se postula como una herramienta que permite pintar a voluntad escenografías que hablen (Revault d'Allonnes, 2008: 16), que cuenten historias, con lo que no resulta extraño que un recurso tan controlable y flexible se haya convertido en una herramienta tan utilizada por la vocación 
profundamente controladora y manipuladora del cine clásico. En definitiva, pintar a voluntad lo que queremos ver en pantalla, pintar cine, es la quintaesencia del cine ultra-controlado tal y como lo entiende el clasicismo.

\section{El matte painting en el régimen de escritura barroco}

El régimen clásico, construido a partir de sus bien establecidos imperativos de verosimilitud, ocultación y legibilidad y su apoyo decidido al sentido, tiene tendencia a caer en una dinámica de estandarización de sus fórmulas que en ocasiones termina derivando en el empobrecimiento de su propio lenguaje y en un academicismo falto de valor expresivo.

Una alternativa contra esta tendencia estandarizante la representa el régimen barroco, también denominado manierista o post-clásico, el cual toma estructuras clásicas -hasta el punto de que en ocasiones es incluso englobado bajo el paraguas clásico- pero, a diferencia de este, el barroquismo no se pliega al apoyo unidireccional al sentido único, sino que busca la exploración de todos los significados posibles, los obvios y los no obvios, ofreciendo una lectura poliédrica del relato. No da por tanto la espalda al sentido obvio, como sí hará la modernidad, considera el sentido obvio de la narración, pero al mismo tiempo explora la existencia de otros sentidos secundarios. El relato barroco es, por tanto, multisignificante (Revault d'Allonnes, 2008: 29). La escritura barroca busca deliberadamente esta proliferación de sentidos, suscita interpretaciones, explora la ambigüedad. Si el clasicismo orientaba todos los recursos al apoyo de un sentido único e indiscutible aún resultando redundante-era sobresignificante- el manierismo priorizará la exploración de sentidos múltiples aún resultando contradictorio.

Frente a la ocultación clásica, el texto manierista saca a flote la propia escritura; existe aquí una "consciencia de la enunciación" (Vila, 1997: 193). Sabemos que el relato es un discurso y que hay un enunciador tras él, aunque a diferencia del régimen moderno, este es un saber que se nos oculta. Ya no nos hallamos ante una ventana transparente a través de la que vemos el mundo, sino que el relato barroco constituye en sí mismo la puesta en abismo de un relato (Vila, 1997: 191), una narración que somos conscientes que alguien está construyendo para nosotros. Y de la evidencia de un enunciador se deriva una psicología, nos hacemos conscientes de que asistimos a una interpretación personal de los hechos y que, por tanto, estos son susceptibles de interpretaciones alternativas. ¿Hay héroe? Ya no está claro. Los personajes no son buenos o malos, hay luces y sombras. La subjetividad abre el camino a la duda, a la ambigüedad. Ante ello, el autor busca la exploración de esa multiplicidad de interpretaciones, persigue la representación de sentidos múltiples, obvios y no obvios. El cine barroco te dice: "esta es una de las posibles interpretaciones de esta historia".

La desaparición de una mirada única hace desaparecer la identificación de la cámara con el lugar del príncipe y en su lugar la cámara pasa a representar una mirada psicológica. Con ello la mirada se hace poliédrica, se rompe la linealidad del montaje y la continuidad espacial clásica, lo que permite que el espacio en sí se psicologice, se metaforice. La evidencia del artefacto narrativo y la subjetivación de los recursos permiten suavizar la exigencia de verosimilitud, admitiendo una mayor teatralidad, consintiendo una marcación más extrema. Abunda la intensidad y el dramatismo en los encuadres

114 | n²2, pp. 105-127 | doxa.comunicación 
y las iluminaciones, el claroscuro, al tiempo que el espacio se distorsiona, se amplifica, se vuelve laberíntico, hiperbólico -citemos simplemente el laberinto de espejos en La dama de Shanghai (Orson Welles, 1947) o el enfoque de gran profundidad en Ciudadano Kane (Orson Welles, 1941)-.

¿Sería posible identificar estas características en los matte paintings de este régimen? ¿Cabría hablar de un matte painting barroco? Para responder a esta pregunta no tenemos más que estudiar los matte paintings de Ciudadano Kane, pintados por Mario Larrinaga, Chelsey Bonestell y Fitch Fulton. Por ejemplo, en el matte painting que muestra la vista exterior de la fachada del diario "Inquirer" en el plano en que los empleados se asoman a la ventana para felicitar a Kane por su próxima boda, se reconocen estas señas de identidad de la escenografía manierista. La imagen está compuesta a partir de un pequeño fragmento de escenario real -dos parejas de ventanas adyacentes por las que se asoman los empleados- $\mathrm{y}$ todo el resto del cuadro es completado con una pintura (figura 04). Aquí el escenario pintado adquiere mucha más importancia que los personajes. La imponente fachada de ladrillo recorre todo el primer plano hasta perderse al fondo a la izquierda sin dejar apenas "aire" en el encuadre, metáfora de la vocación monopolista del imperio Kane. No vemos en esta pintura una composición nada convencional, sobre todo si la comparamos con la frontalidad del encuadre clásico, y en su lugar encontramos un espacio articulado en torno una vertiginosa diagonal y extraordinariamente dilatado en profundidad.

Otros casos de esta hipertrofia del espacio barroco los vemos por ejemplo en el matte painting del mitin político de Kane o en las vistas interiores de Susan y Kane en Xanadu. Los personajes se reducen y el espacio se agiganta a su alrededor. La puesta en escena se impone al personaje, algo que no habría ocurrido en un matte painting clásico, meticulosamente jerarquizado para mantener al personaje como elemento prioritario del cuadro y evitar que el escenario le reste en protagonismo.

Figura 04. Escenografía significante, más importante que los personajes. Dilatación de la tridimensionalidad del espacio en Ciudadano Kane. Matte painting de Mario Larrinaga, Chelsey Bonestell y Fitch Fulton.
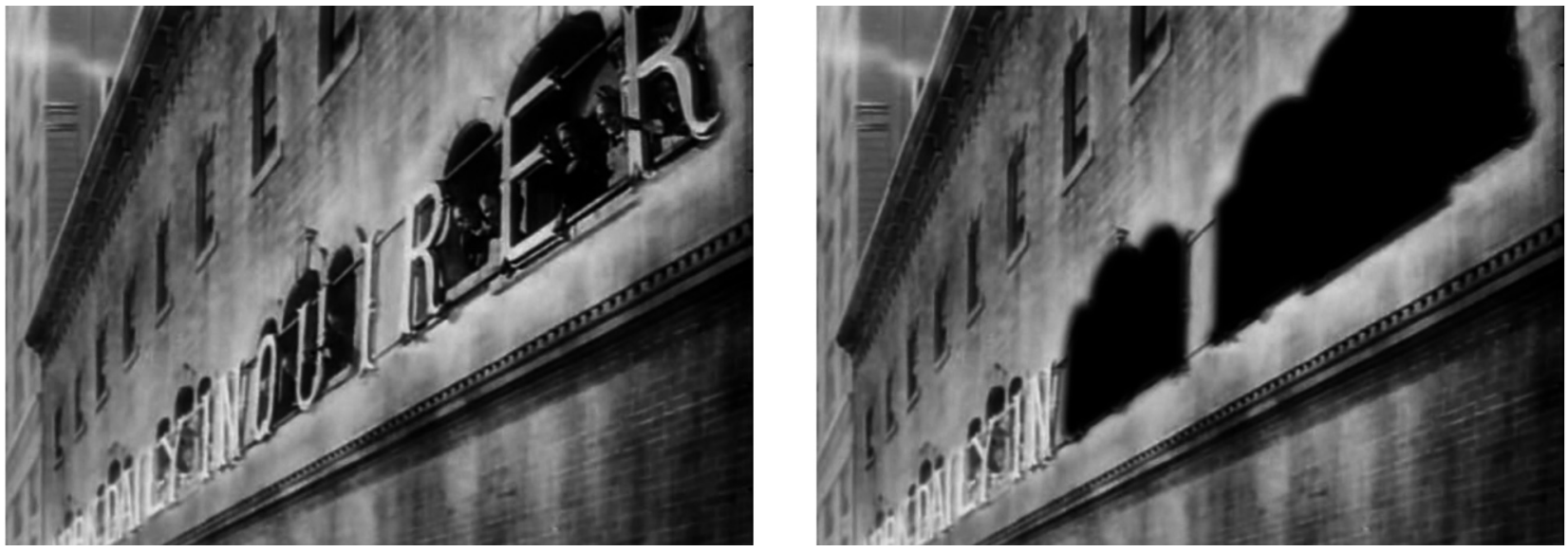

doxa.comunicación | n²2, pp. 105-127| 
Probablemente los matte paintings más memorables del film sean los utilizados para construir la secuencia de apertura, que muestra el exterior de la decadente mansión de Xanadu mediante el encadenamiento de seis planos situacionales que son en realidad seis matte paintings fundidos a modo de falso travelling subjetivo de aproximación hacia la ventana de la habitación en la que fallece Kane. La secuencia arranca con un travelling vertical de la alambrada desde el cartel "No Trespassing”. A continuación, el primer matte painting muestra una vista lejana de la mansión Xanadu desde la verja exterior. El primer plano está ocupado por la "K" de Kane forjada en lo alto del portalón y todo lo que se haya tras la verja es una pintura que muestra la mansión al fondo en lo alto de la colina, en la que una ventana iluminada desde el interior contrasta con la paleta oscura del paisaje nocturno. El punto de vista elegido para la composición es bajo, de manera que la mansión se desplaza a la zona superior de la pintura, próxima al borde. Esta pintura se funde con otra algo más próxima pero casi idéntica en cuanto a composición: una vez traspasada la verja, vemos una jaula con monos del zoológico particular de Kane, aparentemente abandonado, tras el cual se alza la colina con la mansión en su cima, ocupando la misma posición en el encuadre que en el plano anterior (figura 05).

Los siguientes planos, de composición idéntica, son otras tantas pinturas sucesivamente más cercanas que acompañan nuestra aproximación subjetiva a la mansión: unas góndolas en un estanque, el embarcadero, el campo de golf y el portalón de piedra, todo en un decadente y ruinoso estado de desatención. Y por encima de todos ellos siempre se mantiene la ventana iluminada de la habitación, persistentemente colocada en el mismo punto en todos los planos, operando como polo de atracción de la mirada y del discurso. Mantener la ventana iluminada en el mismo punto del encuadre plano tras plano con la precisión que vemos aquí habría sido complejo de no haberse construido la secuencia mediante matte paintings.

Vemos que lo escenográfico se carga de una importante significación psicológica en estas pinturas. En ellas, la irrealidad teatral que desprende el paisaje, la grandeza trágica del escenario, el carácter reiterativo de los encuadres y la repetición obsesiva de la inamovible ventana succionándonos centrípetamente hacia su interior, muestran claramente el tratamiento poderosamente psicológico del relato y el papel del espacio y el escenario en el régimen manierista del que Kane es paradigma. Al igual que para el clasicismo, también encontramos que para el cine barroco el matte painting constituye un recurso extraordinariamente útil al que este régimen ha recurrido si cabe con mayor frecuencia, pues le proporciona el control y la flexibilidad suficientes para construir, descomponer, dilatar, distorsionar y psicologizar el espacio a la medida de las necesidades del relato, de formas que la construcción física resuelve con mayor dificultad. 
Figura 05. La pintura como mirada psicológica. Representación deformada respecto a la visión natural. Hipertrofia de la profundidad de campo y foco profundo en Ciudadano Kane. Matte painting de Mario Larrinaga, Chelsey Bonestell y

Fitch Fulton.
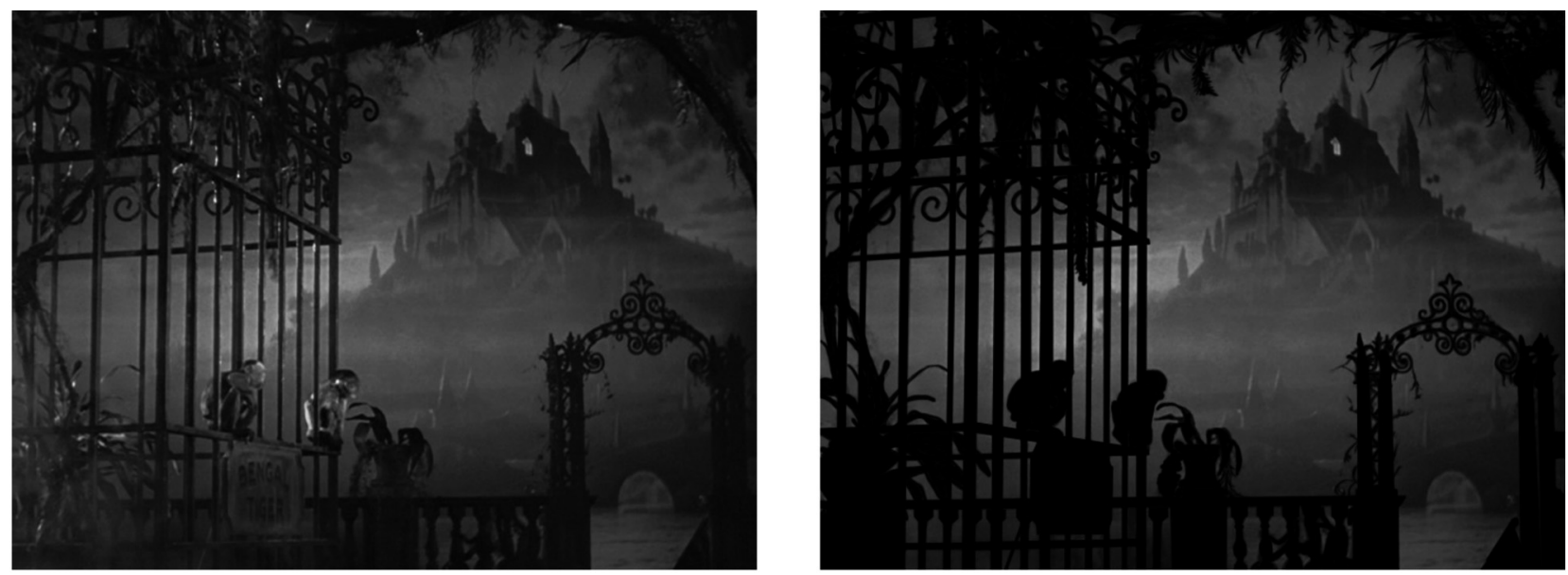

Este rol psicológico del escenario barroco y su elaboración mediante matte paintings son también frecuentes en Hitchcock. Por ejemplo, Cortina Rasgada (Alfred Hitchcock, 1966) recurre a varios matte paintings para ambientar algunas de sus localizaciones, pues el contexto político del momento imposibilitaba el acceso de un equipo de rodaje norteamericano a los lugares reales en el Berlín Oriental. Así, la escena en la que el científico norteamericano Michael Armstrong-Paul Newmanatraviesa el museo Alte Nationalgalerie en un intento de librarse del agente alemán que le sigue, fue realmente construida mediante seis matte paintings obra del artista Albert Whitlock. Tras acceder al museo, Armstrong recorre el vestíbulo principal, dos galerías y unas escaleras que son realmente pinturas de Whitlock. Los espacios interiores y los desplazamientos de los personajes a través de ellos se organizan recurrentemente en profundidad, acentuando la tridimensionalidad del espacio al estilo de Kane. A su vez, los tramos de escaleras fragmentan dicotómicamente el espacio en varios niveles provocando una pluri-focalidad del espacio, que se despliega como un laberinto en las tres dimensiones (figura 06). El escenario representado en estas pinturas, complejo, laberíntico, desafiante, diseñado para imponerse al personaje, la profundidad y multidimensionalidad del espacio en varios niveles y su marcada densidad psicológica -elementos tan propios del manierismo hitchcockiano como del wellesiano- nos permiten describir estos matte paintings como indudablemente barrocos. 
Figura 06. Espacio laberítico, complejo, multidimensional en Cortina Rasgada. Matte painting de Albert Whitlock.
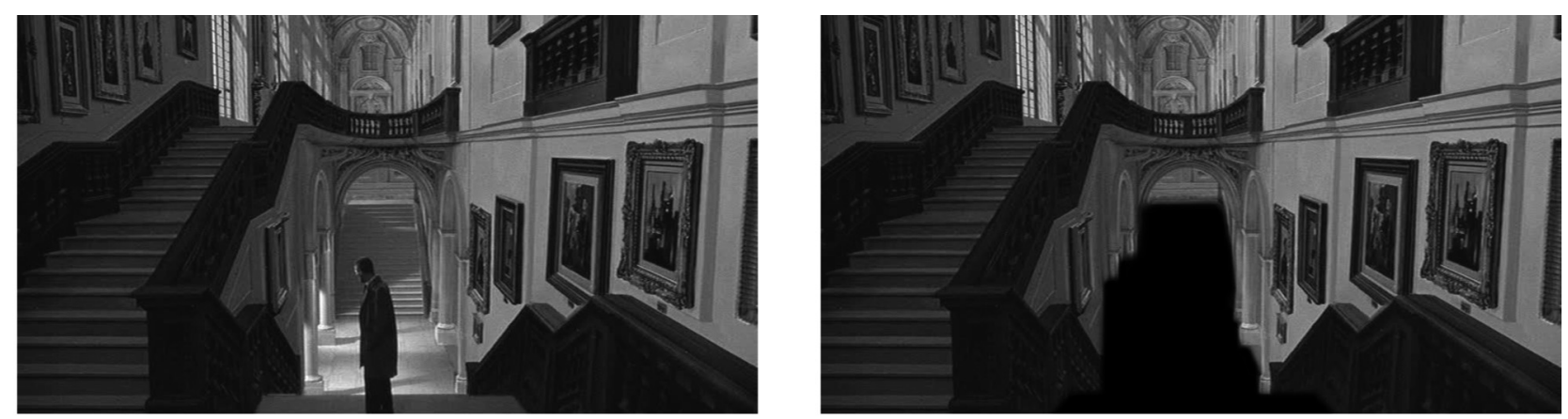

\section{6. ¿Puede existir un matte painting en el régimen moderno?}

Bajo el apelativo de cine moderno, o cine europeo de autor, se engloba un conjunto variopinto de propuestas cinematográficas ligadas por una común necesidad de ruptura con la retórica del clasicismo y su aparato excesivamente codificante y un retorno a la realidad, con sus bellezas y fealdades, pero en la medida de lo posible libre de un exceso de manipulación exterior. Incluimos bajo este paraguas moderno movimientos como el Neorrealismo italiano posterior a la Segunda Guerra Mundial, la Nouvelle Vague francesa o el Free Cinema inglés de la década de los sesenta.

Para este cine la realidad va a ser el patrón por el que regirse, en oposición al idealismo verosímil del clasicismo que nunca ha manifestado interés alguno por retratar realidades. La modernidad por el contrario vuelve la mirada al mundo en busca de su verdad, emerge una aspiración por capturar la realidad en bruto, por retratar su autenticidad. En clara oposición a la sobresignificación clásica, el cine moderno trata de anular o al menos reducir al mínimo el aporte de significado. Se busca resaltar esa ausencia de sentido que caracteriza al mundo real, subrayar su indiferencia ante nuestras acciones. Es por ello que el cine moderno puede calificarse como infrasignificante (Revault d'Allonnes, 2008: 29). También la actitud de la escritura fílmica moderna es opuesta a la clásica: donde en el clasicismo la escritura aspira a ser transparente, aquí ocupa un papel dominante (Vila, 1997: 191), llama la atención sobre sí misma, la construcción cinematográfica y su dispositivo adquieren protagonismo y aportan significado al texto. Aquí hay cámara, autor, pantalla y espectador. El cine moderno te dice: "esto es una filmación cinematográfica".

El cine moderno busca que el escenario permanezca indiferente a la narración, que no participe en el sentido del relato, ni subrayándolo ni contradiciéndolo, a imitación de la vida real donde el espacio, preexistente, no se predispone a subrayar nuestras acciones, nuestros sentimientos o nuestra disposición psicológica. El único sentido por tanto que se admite en la escenografía moderna es el "no sentido" del mundo (Revault d'Allonnes, 2008: 12). De aquí se desprende el impera- 
tivo moderno de no intervenir o intervenir mínimamente en las localizaciones, tanto exteriores como interiores, citemos por ejemplo las localizaciones de Roma, ciudad abierta (Roberto Rossellini, 1945) o Al final de la escapada (Jean-Luc Godard, 1960), o los decorados de Pickpocket (Robert Bresson, 1959), construidos para el rodaje pero en los que se prioriza la neutralidad frente al dramatismo.El autor moderno prefiere no intervenir y cuando lo hace interviene poco y siempre en el sentido de la neutralidad, de la infrasignificancia. La única intervención que se aconseja en el escenario será para neutralizar cualquier atisbo de sentido que pueda desprenderse de él por accidente.

¿Y los efectos? Aunque hay una mostración patente de la construcción cinematográfica, el autor moderno busca la inmediatez en la escritura, la espontaneidad, incluso elaborando deliberadamente esta supuesta espontaneidad (Martin, 2008: 21), discurso donde no tienen cabida efectos cosméticos o de ocultación como el matte painting u otros trucajes, a los que considera artificiales por definición. Un recurso que, como hemos visto, resulta tan útil a las escrituras clásica y barroca, tan propensas a diseñar y controlar minuciosamente sus escenarios y cargarlos de significado, y del que el cine moderno preferirá prescindir a causa de la radical intervención en la sustancia fílmica que representa, priorizando una imagen más naturalista, casi documental. El ideal moderno de situar la cámara ante el mundo desnudo tal y como es, o al menos ante una escena mínimamente intervenida, y aprovechar la especificidad fotográfica del cine (Casetti, 2000: 32) resulta por tanto ideológicamente contrario a la creación manufacturada de imágenes a pincel, al cine pintado, al cual ve como un artificio. Esto explica la significativa ausencia que el matte painting experimenta en la cinematografía moderna.

\section{El matte painting en el régimen de escritura postmoderno}

El cine postmoderno se postula como un régimen de escritura caracterizado por el descreimiento en los ideales de la modernidad y al mismo tiempo por la ruptura con la estructura narrativa clásica, la cual trata de derribar desde sus propios códigos. La cualidad estilística postmoderna más característica es el eclecticismo y su figura más arquetípica el pastiche, superposición de estrategias discursivas y elementos de orígenes diversos para, mediante fusión y recombinación fuera de contexto, construir un texto nuevo. La postmodernidad recurre con libertad al apropiacionismo para confeccionar su discurso apoyándose en cualquier referencia cultural preexistente. Se recurre a la alusión a otros textos, a la citación, al empleo libre de arquetipos y convenciones clásicas de género para ponerlos en cuestión, para desregularizar los principios de la narrativa cinematográfica desde los propios códigos de la escritura clásica. Un ejemplo de esta referencialidad genérica, de esta construcción sobre la citación, lo constituye la fusión de géneros que con frecuencia encontramos en el cine postmoderno, como la fusión de cine negro y ciencia ficción en Blade Runner (Ridley Scott, 1982), o la hibridación de drama y videoclip en Romeo + Julieta de William Shakespeare (Baz Luhrmann, 1996) o Moulin Rouge! (Baz Luhrmann, 2001).

Pero este apropiacionismo y su discurso de la alusión no se limita a la cita a recursos nativos del medio cinematográfico. La mirada postmoderna es transmedial, amplía su repertorio de citas a cualquier elemento de la cultura contemporánea 
sin importar su origen. Una de las maneras en que toma forma el pastiche postmoderno es mediante la combinación de estructuras extraídas de otros medios narrativos, como la inserción de secuencias de animación en Asesinos Natos (Oliver Stone, 1994) o de videojuego en La Playa (Danny Boyle, 2000). Como consecuencia de este entretejido transmedial de referencias externas, el film postmoderno posibilita una metarrepresentación autorreferencial, una metareflexión sobre la película misma impensable para la clausura clásica.

Pero el principal cisma con el clasicismo se encuentra también aquí en la desaparición de la unicidad de la mirada, de la orientación del discurso narrativo en la dirección de un sentido único. La mirada postmoderna se emancipada del servicio univoco a la enunciación y de la unicidad de sentido para provocar el desmoronamiento del propio sentido (González Requena, 2007, p. 582). Y desaparecida la tutela unidireccional de la enunciación, la cámara se emancipa también del significado simbólico de su punto de vista y se concentra en su función puramente escópica, adquiriendo libertad total para situarse "allí donde mejor pueda acentuarse el goce de la mirada" (González Requena, 2007, p. 584), como se puede ver en el libre desplazamiento de la cámara en Amélie (Jean-Pierre Jeunet, 2001) o en Moulin Rouge! Todo ello hace que el cine postmoderno se postule como un dispositivo autorreferencial que disfruta con la mostración del mecanismo del relato, lo que convierte la diégesis en una creación consciente. Aquí todo el relato fílmico se postula como una construcción ficticia autoconsciente. El cine postmoderno te dice: "esto es una fábula cinematográfica".

Este eclecticismo militante, su ambición por romper con cualquier convencionalismo y su cultura del apropiacionismo y la diversidad hacen a la escenografía postmoderna más diversa y difícil de caracterizar desde un punto de vista estético que la de otros regímenes, aunque todavía es posible reconocer en sus matte paintings algunas de sus señas de identidad. Por ejemplo, en Blade Runner, si observamos el plano en que Deckart contempla la ciudad desde su balcón, todo el cuadro salvo el citado balcón es una pintura de Matthew Yuricich (figura 07). El espacio pintado se articula en torno a la calle, utilizada por Yuricich como eje compositivo para distribuir las masas de la imagen y vertebrar la disposición de los bloques arquitectónicos. El diseño de la arquitectura urbana en esta pintura representa la versión pictórica del característico eclecticismo postmoderno. Mezclados entre torres futuristas de trazados luminosos que parecen paneles de neón, se representan otros edificios de aspecto mucho menos moderno que parecen haberse visto obligados a actualizarse para seguir en uso. La actualización de estas infraestructuras se habría realizado mediante lo que Ridley Scott denominó “retrofiting” (Gorostiza y Pérez, 2002, p. 49), que consistiría en la incorporación de sucesivas capas superpuestas de nuevas tecnologías sobre el edificio -tuberías, cableado, instalaciones de aire acondicionado- adosadas por fuera de las fachadas, ofreciendo un aspecto precario, de parcheado continuo, de solución de bajo coste donde la funcionalidad ha sido más urgente que la estética. Mezclado con estos y en primer término, vemos el edificio en el que vive Deckart, de diseño todavía más antiguo, que remite a la arquitectura orgánica de principios de los años 20, en concreto inspirado en el diseño de la Casa Ennis de Frank Lloyd Wright. 
En este plano, con Deckart en el balcón contemplando la ciudad desde lo alto, no encontramos la subordinación clásica del escenario al personaje. Bien al contrario, percibimos una total emancipación o desconexión entre la ciudad pintada y el protagonista, la cual se nos muestra como un ente completamente independiente, dotado de existencia propia, lo que también es una característica de la escenografía postmoderna, su carácter "fractal", por emplear la terminología de Zavala (2005): "la puesta en escena puede ser llamada fractal, lo cual significa que es autónoma frente al personaje y no está sometida a la naturaleza de éste, con el cual establece un diálogo en el que adquiere una importancia similar a la suya, definida por el concepto global de la película".

Figura 07. Carácter fractal del escenario pintado, desconectado del personaje en Blade Runner. Matte painting de Matthew Yuricich.
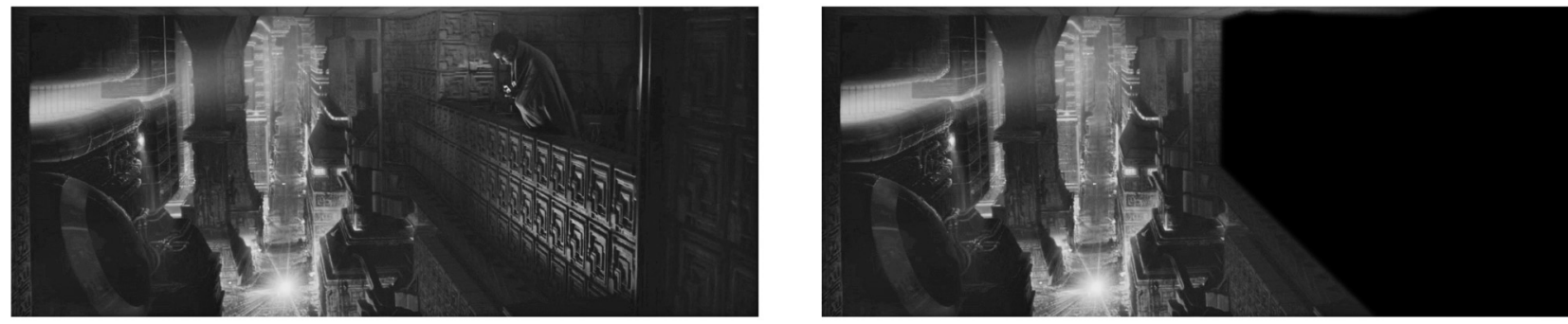

Un poco más adelante, cuando Pris visita la casa de J. F. Sebastian, volvemos a encontrar un matte painting, en este caso obra de la artista Michele Moen, esta vez en una vista a pie de calle (figura 08). De nuevo esta pintura abunda en la acumulación y la mezcla de edificios de distintos estilos y épocas. Aquí, además de las torres futuristas con patrones luminosos y los edificios sobrescritos mediante sucesivas capas de retrofiting, vemos que J. F. Sebastian habita en el edificio Bradbury, un conocido edificio de Los Ángeles diseñado en 1893, que aporta una nota de arquitectura de finales del siglo XIX al conjunto.

Apropiacionismo, reutilización, eclecticismo, combinación aparentemente sin reglas de elementos diversos, préstamo, pastiche, reescritura sobre una escritura anterior, emancipación de la escenografía como entidad autónoma e independiente de los personajes, son las principales características de la escenografía postmoderna y en estos mismos términos se trasmiten y manifiestan en sus matte paintings, de una forma quizás menos consistente o uniforme que en otros regímenes, por la particular diversidad que reivindica la postmodernidad, aunque en cualquier caso resultan detectables y perfectamente reconocibles. 
Figura 08. Pastiche y eclecticismo arquitectónico en Blade Runner. Matte painting de Michele Moen.
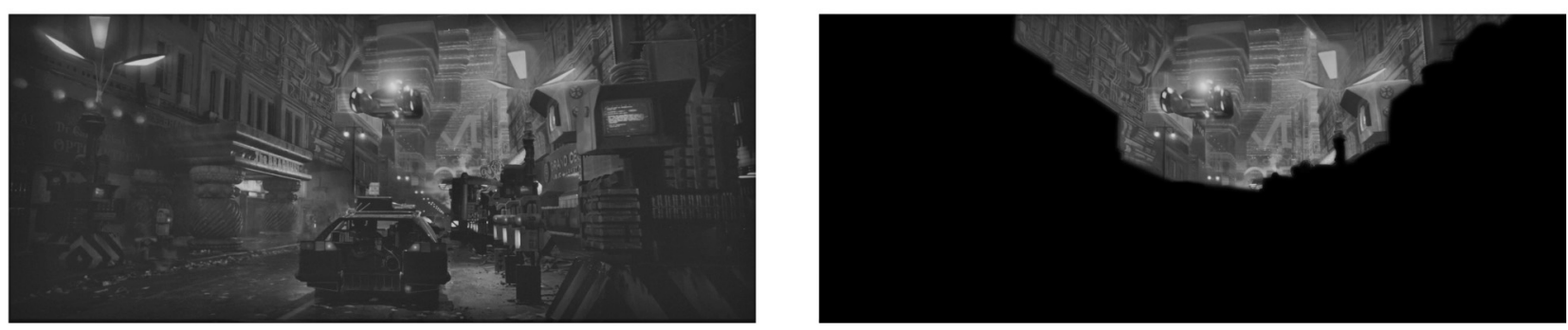

\section{El matte painting en el cine neobarroco digital}

De entre toda la diversidad de propuestas cinematográficas contemporáneas, en este apartado queremos centrarnos en un subconjunto del cine actual, concretamente aquel que emplea la síntesis digital de imágenes y la manipulación y composición digitales para producir un texto con una destacada componente espectacular que reivindica el disfrute de la experiencia visual como parte de su discurso. Es la sensación que Darley (2002: 165) describe como "emoción tecnológica" lo que define la experiencia de consumo de estos productos. Un cine de lo espectacular, inmerso por completo en la cultura postmoderna contemporánea y que no constituye por sí mismo un género, sino una cualidad transversal y común a diversos géneros narrativos.

Así, donde los discursos cinematográficos tradicionales daban prioridad a la historia y los personajes, aquí se añade a los dos elementos anteriores el disfrute del placer visual ante las imágenes vistas. Hablamos por tanto de un cine que redefine el papel de la experiencia sensual y espectacular de la contemplación de sus imágenes, en las que despliega un importante virtuosismo técnico. Esta sería una de las principales características de estos nuevos productos: la mayor relevancia de los atributos formales de su puesta en escena en comparación con los regímenes tradicionales, su mayor intensidad visual. Estos films recurren a la flexibilidad de las nuevas tecnologías y la gran maleabilidad de las imágenes digitales para crear realidades imposibles, para deslumbrar al espectador con la contemplación de lo inverosímil, de lo quimérico. En cierta medida se puede considerar, coincidiendo con Riambau, que este nuevo cine de lo espectacular reivindica un retorno al cine de la sorpresa, "al cine de los orígenes, nacido de los espectáculos de feria" (Riambau, 2011: 17).

En este conjunto de producciones al que nos referimos, para las que la imagen de síntesis juega un papel destacado, puede detectarse un significativo número de características comunes que nos permiten hablar de una estética de lo digital o estética de lo virtual, más próxima a lo barroco que a lo clásico, moderno o postmoderno, aunque sin la intensidad psicológica manierista. Una estética que actualiza los códigos barrocos y los dilata hasta el exceso, coincidiendo con lo que 
Calabrese (1987) denomina "neobarroco". En su estudio sobre esta estética neobarroca, Calabrese manifiesta que en la actualidad vivimos sumergidos en un movimiento cultural caracterizado por la acumulación y el exceso, tanto de forma como de contenido, por la desmesura cuantitativa y cualitativa, nuestro mundo prefiere incitar a la desestabilización y transgresión de los esquemas tradicionales y al derribo de todo límite.

En esta cultura de lo excesivo, el cine de este régimen disfruta también con la inestabilidad y el dinamismo, el monumentalismo y el gigantismo, lo monstruoso y lo grotesco, y las tecnologías digitales facilitan enormemente esta ambición. Podríamos citar Avatar (James Cameron, 2009) como un ejemplo arquetípico de esta estética del exceso. Pandora, el planeta donde transcurre la acción, se nos muestra como un mundo inmenso, masivo, en el que cada una de sus vistas, paisajes y selvas, elaborados hasta el más mínimo detalle para desbordar al espectador, son grandiosos en extensión y de una riqueza exuberante hasta el exceso. El cine neobarroco digital te dice: "esto es un espectáculo visual".

Además de esta tendencia a la desmesura, la mirada neobarroca también se complace con lo enigmático y lo misterioso, lo complejo y lo inextricable, lo laberíntico, la vaguedad y la indefinición. A este respecto, el ejemplo quizás más paradigmático lo constituya la confusión de identidad, la oscuridad de los espacios y la ambigüedad en cuanto a lo que es realidad y lo que es ficción que encontramos en Matrix (Andy Wachowski y Lana Wachowski, 1999)o en Origen (Christopher Nolan, 2010).

Una vez reconocida esta cultura neobarroca actual cabe preguntarse ¿qué papel juega la escenografía, y en concreto el matte painting, en el cine de esta estética? ¿Podríamos identificar las características de la estética neobarroca digital en sus matte paintings? ¿Sería posible hablar de un matte painting neobarroco digital? La respuesta no deja lugar a dudas.

Si observamos los matte paintings presentes en el cine neobarroco digital, la primera característica que llama la atención es su tamaño, la amplitud de su mirada y del espacio que retratan. Si nos fijamos en los paisajes de Minas Tirith en El Señor de los Anillos: Las Dos Torres (Peter Jackson, 2002), obra de Roger Kupelian, o en los campos de Pelennor pintados por Dylan Cole para El Señor de los Anillos: El Retorno del Rey (Peter Jackson, 2003), nos deslumbra la vastísima extensión de los paisajes (figura 09). Estas pinturas muestran llanuras inabarcables que se extienden más allá de los límites de la pantalla, como si se tratara de un mundo tan enorme que resultara imposible abarcarlo con la vista, mayor de lo que se puede imaginar. Imagen dilatada en exceso, inabarcable, extasiante, que busca desbordar la mirada y donde la escenografía se impone a la esfera de lo humano y lo reduce. Esta hipertrofia la encontramos en muchos matte paintings de este régimen como, por citar un ejemplo, en la fortaleza de Minas Morgul en El Retorno del Rey, también pintada por Dylan Cole. La fortaleza, su estructura, sus murallas y sus torres, se han representado desproporcionadamente altos, imponentes, descomunales, y la iluminación a contraluz sirve para multiplicar este efecto, de forma que la escala de los personajes resulta empequeñecida, abrumada. 
Otra tendencia al gigantismo, en este caso gigantismo urbanístico, la encontramos en las vistas del planeta Coruscant en Star Wars: Episodio III - La Venganza de los Sith (George Lucas, 2005) pintadas por Yanick Dusseault (figura 10). Estas pinturas muestran un planeta masivamente superpoblado en que la construcción urbana se extiende hasta el horizonte, produciendo un patrón visual constante, modular, repetitivo, infinito, ocupando cada centímetro del cuadro sin dejar hueco libre ni descanso a la mirada. Tendencia al exceso hasta la extenuación de la vista. El trazado, laberíntico, anula el sentido de la orientación y por tanto la legibilidad y aprehensión del espacio, prefiriendo perderse en el "placer del extravío" (Calabrese, 1987: 156). En estos matte paintings la imagen busca resultar desorientadora, indescifrable.

Figura 09. La pintura busca desbordar la mirada. Espacio inabarcable en El Retorno del Rey. Matte painting de Dylan Cole.

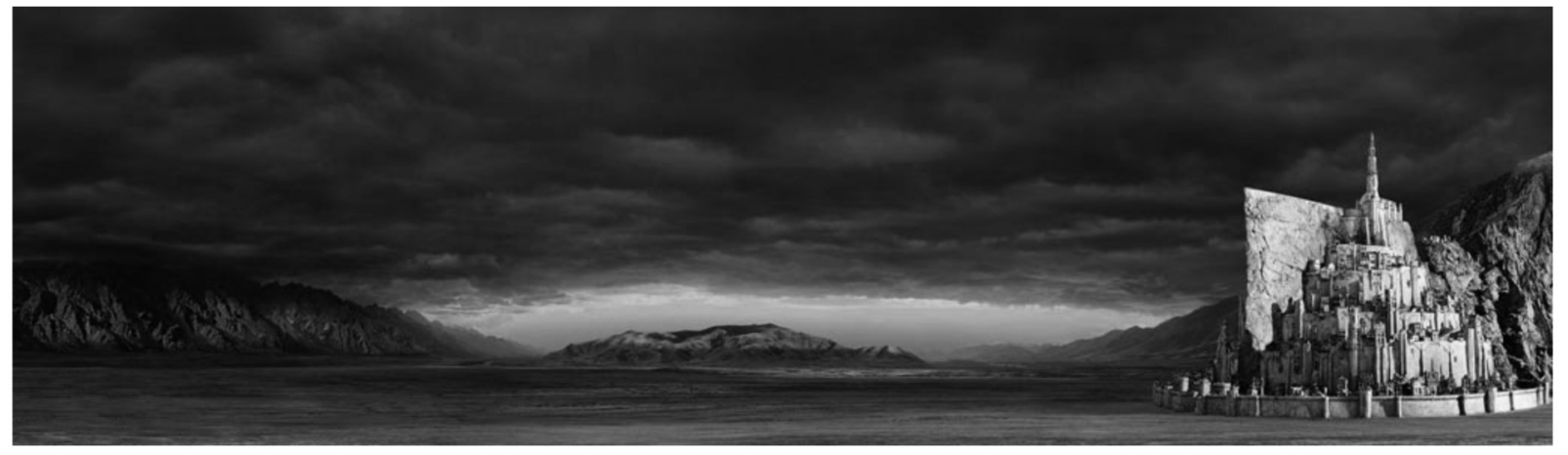

Figura 10. Representación urbana masiva, excesiva, desorientadora en La Venganza de los Sith. Matte painting de Yanick Dusseault.

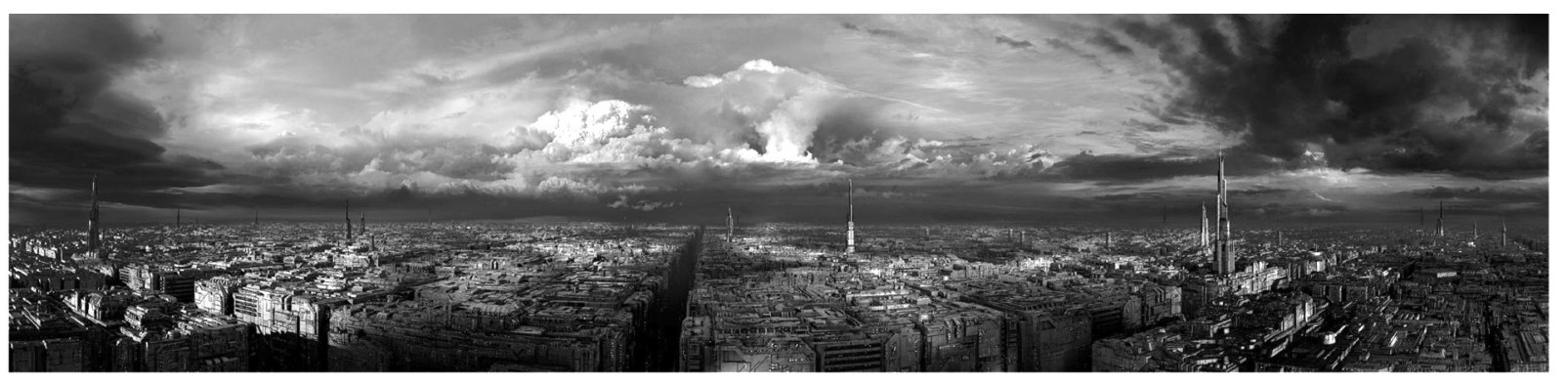

Otra de las señas de identidad neobarroca que hemos destacado es su preferencia por lo inquietante, lo amenazante, características que aparecen también constante y claramente reconocibles en muchas pinturas de este régimen. Como ejemplo baste citar las vistas del paisaje de Mordor en Las Dos Torres pintadas por Roger Kupelian. La cadena montañosa 
que se alza intimidante sobre la llanura y que se recorta contra el cielo negro gracias al contraluz provocado por el resplandor rojo que emana del Monte del Destino, provoca una angustiosa sensación de inquietud, de inestabilidad, de calma que precede a la tempestad, como una declarada amenaza visual de la inminencia del ataque, del que es inútil escapar. Esta tendencia a la inestabilidad encuentra su máxima expresión en el gusto neobarroco por la destrucción y el caos, el "caos como arte" que también cita Calabrese (1987: 141). Caos abrumador, sin albergar descanso, excesivo, exceso incluso de caos. Esta destrucción abrumadora la encontramos retratada en matte paintings como los de la llanura de Isengard en $E l$ Señor de los Anillos: La Comunidad del Anillo (Peter Jackson, 2001) pintados por Paul Campion, o en el San Francisco pintado por Roger Kupelian para Terminator Salvation (McG, 2009), que retratan una ciudad devastada, apocalíptica, un amasijo caótico de edificaciones demolidas, en ruinas hasta donde alcanza la vista.

Otra característica muy reconocible de estas pinturas en cuanto a gama cromática y lumínica es su preferencia por la oscuridad, por la negrura (López Silvestre, 2004), un recurso utilizado para materializar la inclinación neobarroca por lo nebuloso, lo indescifrable, lo sombrío. En las vistas de la ciudad subterránea de Sión en Matrix Reloaded (Andy Wachowski y Lana Wachowski, 2003) y Matrix Revolutions (Andy Wachowski y Lana Wachowski, 2003) pintadas por Richard Mahon, domina una paleta de negros y grises profundos, una representación en sombras de una ciudad clandestina, el último reducto en que se puede refugiar la vida, pero que en el fondo resulta una vida furtiva, de ocultación, entre sombras, sin luz ni esperanza. Misma sombra, misma oscuridad impenetrable, la encontramos en los matte paintings de la secuencia del puente de Khazad-Dûm en Moria en La Comunidad del Anillo, pintados por Paul Campion. El interior del entorno cavernoso y el precipicio rocoso de profundidad inexpugnable se encuentran sumidos en una oscuridad casi absoluta que prácticamente anula la vista.

Todo esto nos permite afirmar la existencia de un conjunto de características comunes a los matte paintings de la nueva cinematografía digital de espectáculo, reconocibles en el intenso barroquismo visual de sus propuestas estéticas basadas en el exceso, exceso que resulta facilitado y multiplicado por la infinita versatilidad de la imagen electrónica de síntesis en que se apoya la contemporánea mirada neobarroca.

\section{Conclusiones}

Los resultados de este análisis muestran cómo el matte painting, en tanto que recurso del diseño escenográfico, ha sido adaptado por los diversos regímenes de escritura a sus particulares características discursivas hasta el punto de que es posible inferir el régimen de escritura a partir de las características de la pintura.

Así, vemos cómo en el sobresignificante régimen clásico los matte paintings aparecen exquisitamente compuestos, nítidamente legibles y se subordinan a los personajes en favor del sentido obvio del relato sin ambigüedades. Por su parte, el multisignificante régimen barroco otorga una mayor densidad psicológica al escenario pintado en el matte painting, hi- 
pertrofiando el espacio y mostrándolo más importante que el personaje, en busca de sentidos obtusos. El escenario en el régimen postmoderno resulta más difícil de categorizar por su carácter ecléctico y su ambición por romper arquetipos, pero todavía pueden identificarse en muchos de sus matte paintings características típicamente postmodernas como su tendencia al apropiacionismo, a la citación, a la reescritura, o como la emancipación de la escenografía como entidad autónoma y desconectada de los personajes. Por último, el régimen neobarroco digital explora el disfrute de la experiencia espectacular de sus imágenes y se vale de la flexibilidad de las herramientas digitales para la creación de realidades imposibles, quiméricas. Sus matte paintings desbordan la mirada con paisajes inabarcables e imponentes, o representan entornos excesivos, extenuantes, desorientadores, que abundan en la hiperpoblación o en la destrución más absoluta, y muestan ambientes sombríos, amenazantes e inquietantes.

Resulta destacable también la ausencia del matte painting en la escritura moderna, que lo rechaza en busca de un registro más espontáneo e inmediato de una realidad en principio menos intervenida.

Quedaría pendiente prolongar el estudio al modo de representación primitivo, para tratar de identificar si en los relativamente escasos e inaugurales ejemplos de matte painting que se desarrollaron en dicho período, pudieran aislarse algunas características comunes que nos permitieran hablar de un matte painting típicamente primitivo como sí sucede en las restantes escrituras.

\section{Referencias bibliográficas}

\subsection{Bibliografía}

Bordwell, D. S. (1997): El cine clásico de Hollywood. Estilo cinematográfico y modo de producción hasta 1960. Buenos Aires: Paidós.

Calabrese, O. (1987): La era neobarroca. Madrid: Cátedra.

Casetti, F. (2000): Teorías del cine. 1945-1990. Madrid: Catedra. Signo e imagen.

Darley, A. (2002): Cultura visual digital. Espectáculo y nuevos géneros en los medios de comunicación. Barcelona: Paidós. González Requena, J. (2007): Clásico, marierista, postclásico. Los modos del relato en el cine de Hollywood. Valladolid: Castilla.

Gorostiza, J. y. Pérez, A. (2002): Blade Runner. Ridley Scott. Barcelona: Paidós Películas.

López Silvestre, F. (2004): El paisaje virtual. El cine de Hollywood y el neobarroco digital. Madrid: Biblioteca Nueva.

Martin, A. (2008): ¿Qué es el cine moderno? . Santiago de Chile: Uqbar. 
Mattingly, D. (2011): The digital matte painting handbook. Indianapolis, Indiana: Wiley.

Revault d'Allonnes, F. (2008): La luz en el cine. Madrid: Cátedra. Signo e Imagen.

Riambau, E. (2001): Hollywood en la era digital. Madrid: Cátedra.

Rickitt, R. (2006): Special effects. London: Aurum Pr.

Sawicki, M. (2007): Filming the fantastic. Amsterdam: Focal Press.

Vaz, M. and Barron, C. (2002): The invisible art. San Francisco: Chronicle Books.

Vila, S. (1997): La escenografía. Cine y arquitectura. Madrid: Cátedra. Signo e imagen.

\subsection{Referencias electrónicas}

Zavala, L. (2005): “Cine Clásico, Moderno y Posmoderno”, Razón y Palabra, n. 46. Disponible en: http://www.razonypalabra.org.mx/anteriores/n46/lzavala.html [Consultado el 21/09/15]. 